\title{
Potential for Offsetting Diamond Mine Carbon Emissions through Mineral Carbonation of Processed Kimberlite
}

\author{
Evelyn M. Mervine1, Gregory M. Dipple², Ian M. Power², Siobhan A. Wilson ${ }^{3}$, Gordon \\ Southam $^{4}$, Colette Southam ${ }^{5}$, Juerg M. Matter ${ }^{6}$, Peter B. Kelemen ${ }^{7}$, Johann \\ Stiefenhofer $^{8}$, and Zandile Miya ${ }^{1}$
}

${ }^{1}$ The De Beers Group of Companies, Johannesburg, South Africa, Evelyn.Mervine@ debeersgroup.com, Zandile.Miya@debeersgroup.com

${ }^{2}$ The University of British Columbia, Vancouver, Canada, gdipple@eoas.ubc.ca, ipower@eoas.ubc.ca

${ }^{3}$ Monash University, Melbourne, Australia, sasha.wilson@monash.edu.au

${ }^{4}$ University of Queensland, Brisbane, Australia, g.southam@uq.edu.au

${ }^{5}$ Bond University, Brisbane, Australila, csoutham@bond.edu.au

${ }^{6}$ University of Southampton, Southampton, United Kingdom, J.Matter@southampton.ac.uk

7 Columbia University, New York City, USA, peterk@ldeo.columbia.edu

${ }^{8}$ Anglo American Operations Ltd., Johannesburg, South Africa, Johann.Stiefenhofer@debeersgroup.com

\section{Introduction}

There is enormous untapped potential for offsetting diamond mine carbon emissions through mineral carbonation of processed kimberlite. Mineral carbonation, also referred to as carbon mineralization, is the storage of carbon dioxide in stable carbonate minerals (e.g. Power et al., 2013, 2014). The formation of secondary carbonate alteration minerals, many of which form at low temperatures and pressures and sequester substantial quantities of atmospheric carbon, is a well-recognized pathway for storing carbon in mafic and ultramafic rocks, such as basalts and peridotites (e.g. Matter and Kelemen, 2009; Power et al., 2009). Limited studies have been conducted on kimberlites, but it is expected that atmospheric carbon is also sequestered in these rocks through both natural (e.g. in situ alteration of kimberlite pipes) and artificially enhanced (e.g. accelerated carbonation rates in processed kimberlite) formation of secondary carbonates. Understanding the various origins (e.g. primary magmatic vs. high temperature hydrothermal vs. low temperature secondary) of carbonates in kimberlite pipes and in processed kimberlite is critical in order to understand the carbonation rates and enhanced carbonation potential of kimberlite. Furthermore, it is important to be able to trace the sources of incorporated carbon (e.g. atmospheric carbon vs. recycled magmatic or bedrock carbon).

Although on-going low temperature carbonation reactions have been observed in kimberlite pipes (for example, in the Attawapiskat region of Canada, e.g. Sader et al., 2007) and it is well-recognized that processed kimberlite is highly suitable for sequestration (for example, by the Carmex Project, Bodénan et al., 2014), only a handful of studies have previously investigated carbonation at specific diamond mines. Furthermore, these studies have focused on two mining operations (Diavik and Ekati) in the Canadian Arctic, with detailed work only having been carried out at Diavik (e.g. Rollo and Jamieson, 2006; Wilson et al., 2009, 2011). Carbonation of processed kimberlite at Diavik is rapid: two orders of magnitude faster than the natural rate (Wilson et al., 2011), even under unfavorable conditions (i.e. subaqueous storage in an arctic climate). Deliberate acceleration of carbonation of the processed kimberlite produced annually at Diavik has the potential to offset up to 10x the mine's carbon emissions (Wilson et al., 2011).

The goal of this study is to present additional information on the mineral carbonation potential of kimberlite mines. Detailed mineralogical characterization studies to assess carbonation potential have 
been undertaken on processed kimberlite samples from the De Beers mine site Venetia in South Africa, as well as from the De Beers mine sites Victor, Gahcho Kué, and Snap Lake in Canada.

\section{Analytical Results}

Qualitative mineralogical composition data for fresh (recently-deposited, rather than historical) fine processed kimberlite samples from five diamond mines in South Africa and Canada are listed in Table 1. The mineral contents were estimated from the relative intensity of peaks using powder X-Ray diffraction data. These processed kimberlite samples have considerable diversity in mineral content, which reflects variable conditions of kimberlite magmatism and emplacement, as well as subsequent alteration processes. The samples also have variable mineral surface area, which is indicated in the table as Brunauer-Emmett-Teller (BET) surface area (Brunauer et al., 1938).

\begin{tabular}{|c|c|c|c|c|c|}
\hline Minerals & Venetia & Diavik & Victor & Gahcho Kué & Snap Lake \\
\hline $\begin{array}{c}\text { Tectosilicates } \\
\text { K-feldspar } \\
\text { Plagioclase } \\
\text { Quartz }\end{array}$ & $\mathrm{m}$ & $\begin{array}{c}m \\
t\end{array}$ & $t$ & $\begin{array}{c}m \\
t \\
t\end{array}$ & $\begin{array}{l}\mathrm{m} \\
\mathrm{M} \\
\mathrm{m}\end{array}$ \\
\hline $\begin{array}{c}\text { Phyllosilicates } \\
\text { Chlorite } \\
\text { Mica } \\
\text { Serpentine } \\
\text { Smectite } \\
\text { Talc }\end{array}$ & $\begin{array}{l}M \\
M \\
M\end{array}$ & $\begin{array}{l}\mathrm{m} \\
\mathrm{M} \\
\mathrm{m}\end{array}$ & $\begin{array}{c}\mathrm{t} \\
\mathrm{t} \\
\mathrm{M}\end{array}$ & $\begin{array}{l}\mathrm{m} \\
\mathrm{M} \\
\mathrm{M} \\
\mathrm{M} \\
\mathrm{M}\end{array}$ & $\begin{array}{c}M \\
M \\
M \\
t \\
m\end{array}$ \\
\hline $\begin{array}{l}\text { Inosilicates } \\
\text { Amphibole } \\
\text { Clinopyroxene } \\
\text { Orthopyroxene }\end{array}$ & $\begin{array}{l}\mathrm{m} \\
\mathrm{M}\end{array}$ & $\mathrm{t}$ & $\begin{array}{l}t \\
t\end{array}$ & $\mathrm{t}$ & \\
\hline $\begin{array}{c}\text { Orthosilicates } \\
\text { Garnet } \\
\text { Olivine }\end{array}$ & $t$ & $\begin{array}{c}\mathrm{t} \\
\mathrm{M}\end{array}$ & $M$ & & \\
\hline $\begin{array}{c}\text { (Hydr)oxides } \\
\text { Brucite } \\
\text { Spinels }\end{array}$ & $\mathrm{t}$ & & $\begin{array}{l}t \\
t\end{array}$ & & \\
\hline $\begin{array}{c}\text { Carbonates } \\
\text { Calcite } \\
\text { Dolomite } \\
\text { Magnesite } \\
\text { Siderite }\end{array}$ & $\mathrm{m}$ & $\mathrm{m}$ & $\begin{array}{c}M \\
M \\
t \\
t\end{array}$ & $\begin{array}{c}\mathrm{m} \\
\mathrm{t}\end{array}$ & $\begin{array}{l}\mathrm{m} \\
\mathrm{m}\end{array}$ \\
\hline $\begin{array}{l}\text { BET surface } \\
\text { area }\left(\mathrm{m}^{2} / \mathrm{g}\right)\end{array}$ & 13.8 & 48.0 & 21.4 & 46.2 & 24.7 \\
\hline
\end{tabular}

Table 1: Detailed mineralogical composition of the De Beers processed kimberlite samples, compared with previous results from Diavik (Wilson et al., 2009). Note that $\mathrm{M}=$ major, $\mathrm{m}=$ minor, and $\mathrm{t}=$ trace.

\section{Discussion and Conclusions}

Because kimberlites display considerably mineralogical diversity, detailed characterization of processed kimberlite samples is essential in order to assess the mineral carbonation potential of specific diamond mine sites, as well as the technologies that could potentially be employed to enhance carbonation. Despite their mineralogical diversity, all of the processed kimberlite samples presented in this study contain abundant minerals with carbonation potential. Minerals of particular interest for reactivity with carbon dioxide include serpentine, olivine, brucite, talc, smectite, and chlorite. The major minerals, such as serpentine, provide the bulk of the carbonation potential. However, the presence of minor and trace minerals is also important, particularly for minerals such as brucite and talc that are easily carbonated under low pressure and temperature conditions. The surface areas of the processed kimberlite also vary. The samples with the highest surface areas are likely to be easiest to carbonate. Overall, the new mineralogical results from De Beers mine sites concur with the previous research at 
Diavik that enhanced mineral carbonation of processed kimberlite has the potential to offset up to $10 \mathrm{x}$ the carbon emissions of a diamond mine.

Previous research (e.g. Power et al., 2013, 2014) has demonstrated that carbonation rates in ultramafic mine wastes are highly variable and controlled by factors such as: (1.) the nature of ore, gangue, and alteration mineralogy; (2.) mineral processing and mine design; (3.) tailings handling and storage; (4.) local climate; and (5.) biology. Additional research, particularly on historical tailings, is required to assess what factors are limiting carbonation reactions at the De Beers mine sites assessed in this study. Once the factors limiting carbonation have been identified, then technologies to accelerate carbonation can be identified and tested, first at the laboratory-scale and then at pilot scales on the mine sites.

Tapping into the full carbonation potential of processed kimberlite is not likely to be economically or practically achievable at diamond mines in the near future. However, carbonating even a small percentage of processed kimberlite could lead to substantial carbon offsets or even carbon neutral mining operations and will likely be feasible, using existing technologies, in the near future. Laboratoryscale studies (e.g. Power et al., 2013, 2014) indicate that carbonation rates of ultramafic mine tailings can be increased by orders of magnitude by targeting rate-limited reactions, such as $\mathrm{CO}_{2}$ supply and mineral dissolution. Technologies that could be employed to enhance carbonation include $\mathrm{CO}_{2}$ injection and biotechnologies, such as bioreactors. In addition, making simple, low-cost physical changes to processed kimberlite storage, such as depositing thinner layers of tailings, could also enhance carbonation rates.

\section{References}

Bodénan, F., Bourgeois, F., Petiot, C., Augé, T., Bonfils, B., Julcour-Lebigue, C., Guyot, F., Boukary, A., Tremosa, J., Lassin, A., Gaucher, E.C., and Chiquet, P. (2014) Ex situ mineral carbonation for $\mathrm{CO}_{2}$ mitigation: Evaluation of mining waste resources, aqueous carbonation processability, and life cycle assessement (Carmex project). Minerals Engineering 59: 52-63.

Brunauer, S., Emmett, P. H., and Teller, E. (1938) Adsorption of Gases in Multimolecular Layers. Journal of the American Chemical Society 60: 309-319.

Matter, J. M. and Kelemen, P. B. (2009) Permanent storage of carbon dioxide in geological reservoirs by mineral carbonation. Nature Geoscience 2: 837-841.

Power, I.M., Wilson, S.A., Thom, J.M., Dipple, G.M., Gabites, J.E. and Southam, G. (2009) The hydromagnesite playas of Atlin, British Columbia, Canada: A biogeochemical model for $\mathrm{CO}_{2}$ sequestration. Chemical Geology 260: 286-300.

Power, I.M., Harrison, A.L., Dipple, G.M., Wilson, S.A., Kelemen, P.B., Hitch, M. and Southam, G. (2013) Carbon mineralization: From natural analogues to engineered systems, in: DePaolo, D.J., Cole, D.R., Navrotsky, A., Bourg, I.C. (Eds.), Geochemistry of Geologic $\mathrm{CO}_{2}$ Sequestration. The Mineralogical Society of America, Chantilly, Virginia, U.S.A., pp. 305-360.

Power, I.M., McCutcheon, J., Harrison, A.L., Wilson, S.A., Dipple, G.M., Kelly, S., Southam, C. and Southam, G. (2014) Strategizing carbon-neutral mines: A case for pilot projects. Minerals 4, 399436.

Rollo, H. A. and Jamieson, H. E. (2006) Interaction of diamond mine waste and surface water in the Canadian Arctic. Applied Geochemistry 21: 1522-1538.

Sader, J. A., Leybourne, M. I., McClenaghan, M. B., and Hamilton, S. M. (2007) Low-temperature serpentinization processes and kimberlite groundwater signatures in the Kirkland Lake and Lake Timiskiming kimberlite fields, Ontario, Canada: implications for diamond exploration. Geochemistry: Exploration, Environment, Analysis 7: 3-21.

Wilson, S.A., Dipple, G.M., Power, I.M., Barker, S.L.L., Fallon, S.J. and Southam, G. (2011) Subarctic weathering of mineral wastes provides a sink for atmospheric $\mathrm{CO}_{2}$. Environmental Science \& Technology 45: 7727-7736.

Wilson, S., Raudsepp, M., Dipple, G.M. (2009) Quantifying carbon fixation in trace minerals from processed kimberlite: A comparative study of quantitative methods using X-ray powder diffraction data with applications to the Diavik Diamond Mine, Northwest Territories, Canada. Applied Geochemistry 24: 2312-2331. 